\title{
COMPOSITION OF PLECOPTERA (INSECTA) FAUNA IN RIVERS AT DIFFERENT ALTITUDES OF HIGH MOUNTAIN IN PENINSULAR MALAYSIA
}

\author{
AMIRUDDIN, M.N. and SUHAILA, A.H. ${ }^{*}$ \\ School of Biological Sciences, Universiti Sains Malaysia, \\ 11800 Minden, Penang. Malaysia \\ *E-mail: ahsuhaila@usm.my
}

Accepted 9 December 2020, Published online 31 December 2020

\begin{abstract}
The composition of Plecoptera species in rivers at different altitudes in Malaysia is not well understood. Therefore, a study on the diversity of stonefly (Plecoptera) was carried out at Gunung Jerai, Kedah, and Gunung Ledang, Johor. The data were collected from three streams for each Gunung Ledang and Gunung Jerai making a total of six streams; Tupah, Bt Hampar, and Teroi rivers from Gunung Jerai while, Ulu Jementah, Jeram Tinggi, and Anak Air Puteh rivers from Gunung Ledang. Plecoptera nymphs were collected using the kick-net sampling technique. All rivers from both mountains recorded five genera out of three families but Kamimuria was found only in Gunung Jerai while Phanoperla was found in a river at Gunung Ledang. Anak Air Puteh River (975 m a.s.1.) recorded the greatest diversity of plecopterans genus (4) while Tupah River (200 $\mathrm{m}$ a.s.1.), reported the most diverse plecopterans at Gunung Jerai (4). Based on correlation analysis, the plecopterans composition is influenced by water temperature, $\mathrm{pH}$, altitudes, $\mathrm{COD}$, and $\mathrm{BOD}(p<0.05)$. Low $\mathrm{pH}$ values (acidic) at the highest region for both mountains (Teroi and Anak Air Puteh rivers) allowed an acid-tolerant plecopterans (Nemouridae) to thrive in those rivers. The decreasing diversity of Plecoptera taxa from low to high altitudes were affected by the water physicochemical parameters that vary in altitudes, and probably due to the type of vegetative structures.
\end{abstract}

Key words: Aquatic insects, biodiversity, ecosystem services

\section{INTRODUCTION}

Plecoptera or stoneflies are a primitive group of insects that can be found in flowing waters that are clean and well-oxygenated (Ignac \& Catherine, 2012). Aquatic insects can be found almost everywhere in the freshwater ecosystem. According to Zwick (2000), tropical stoneflies have high diversity and comprising of more than 2000 species worldwide. Species diversity of stonefly declines rapidly from temperate Asian latitudes (nine families) to tropical latitudes (four or fewer families) (Ignac \& Catherine, 2012) and family Perlidae is the only diverse stonefly in Malaysia (Suhaila \& Che Salmah, 2011) that well adapted to tropical environments. There are four families of Plecoptera that have been recorded so far from peninsular Malaysia, namely, Perlidae, Peltoperlidae, Nemouridae, and Leuctridae.

\footnotetext{
* To whom correspondence should be addressed.
}

Meanwhile, Plecoptera in the European region is being reduced to small isolated populations due to the growth of organic water pollution lead to the extinction of these species (Fochetti \& de Figueroa, 2008) as the presence of Plecoptera are associated with clean and cold streams (Williams \& Felmate, 1992) as well as highly-oxygenated water (Fochetti $\&$ de Figueroa 2008). According to Bispo et al., (2001), plecopterans are restricted to the mountain and forested area in the tropical region probably due to several environmental factors such as altitude and temperature (Tomanova et al., 2007; Dewalt et al., 2010) that could change the structure and communities of the aquatic insects (Bispo et al., 2001). Instead of growing research in the biodiversity of aquatic insects in the tropical region (Hoang et al., 2010; Al-Shami et al., 2010, 2011), there is poor knowledge on Plecoptera fauna in tropical areas regarding its ecology in the Asian region including their role in the ecosystem stability (Al-Shami et al., 2010, 2011). Plecoptera has been recognized as an excellent bioindicator of water 
quality (Lock \& Goethals, 2008) that is restricted to highly oxygenated water and intolerant of organic as well as thermal pollution (Ratitorn \& Chitchol, 2013). A previous study by Suhaila \& Che-Salmah $(2011,2014)$ had discussed the temporal distribution of Ephemeroptera, Plecoptera, and Trichoptera (EPT) communities and the diversity of their adult's communities in Tupah River. Also, there are studies on the distribution of EPT in tropical rivers influenced by substrate embeddedness and canopy cover (Suhaila \& Che Salmah, 2011), and also the distribution and the diversity of stoneflies in Malaysian tropical rivers as well as Malaysian seasonality (Suhaila \& Che Salmah, 2010). However, a study on the influence of altitudes at high mountains in Peninsular Malaysia has never been conducted In which this information is highly needed to relate the preference of this unique fauna to its habitat. Therefore, this study was carried out to investigate the diversity of stonefly (Plecoptera) nymphs at different altitudes of mountain rivers.

\section{MATERIALS AND METHOD}

\section{Study area}

This study was carried out in Tupah River (200 $\mathrm{m}$ a.s.1.), Bt Hampar River (300 $\mathrm{m}$ a.s.1.) and Teroi River (1214 m a.s.1.) of the Gunung Jerai Forest Reserve, Kedah, and in Ulu Jementah River (151 m a.s.1.), Jeram Tinggi River (286 m a.s.1.) and Anak Air Puteh River (975 m a.s.1) located in Gunung Ledang, Johor.

\section{Sampling of Plecoptera}

Samples of Plecoptera nymph were collected in each river by using the kick-net sampling technique following Meritt et al. (2008), with slight modification by using a D-pond aquatic net $(50 \mathrm{mM}$ mesh). The insects were sampled by placing the net facing the water current of the river. Stream bottom in front of the net was kicked and some of the substrates were lifted and rubbed with hands to dislodge the attached insects into the net. Twenty samples were taken along the $100 \mathrm{~m}$ stretches from each river. The collected insects were sorted and preserved in universals bottles filled with $75 \%$ ethanol (ETOH). In the laboratory, the collected Plecoptera were identified to the genus level using the keys of Yule and Yong (2004), and Jaihao and Phalaraksh (2013).

\section{Water quality parameter}

At each sampling rivers, water samples were collected and kept in polyethylene bottles. The bottles were brought to the laboratory and kept at $4^{\circ} \mathrm{C}$ before being analyzed. Other water parameters such as $\mathrm{pH}$, dissolved oxygen and water temperature at each river were measured in-situ using a YSI Pro Plus handheld meter. Biochemical oxygen demand (BOD), chemical oxygen demand (COD), and total suspended solids (TSS) were analyzed using $\mathrm{HACH}$ manual procedures.

\section{RESULTS}

Tupah River, Batu Hampar, and Anak Air Puteh River reported the most diverse Plecoptera genus from three families (Table 1). Gunung Ledang recorded three families (Perlidae, Peltoperlidae, and Nemouridae) of Plecoptera with three genera of Perlidae (Etrocorema sp., Neoperla sp., Phanoperla sp.), one genus of Peltoperlidae (Cryptoperla sp.), and Nemouridae (Indonemoura sp.). Perlidae were frequently found in all rivers.

Family of Peltoperlidae was recorded in low altitude rivers such as Tupah, Bt Hampar, Ulu Jementah, and Jeram Tinggi rivers but was absent in high elevation rivers. While Nemouridae was only recorded in high altitudes rivers (Teroi and Anak Air Puteh). Phanoperla sp. was absent in all rivers at Gunung Jerai. On the other hand, Kamimuria sp. mostly recorded from Gunung Jerai from Tupah and Bt. Hampar rivers and none were recorded from Gunung Ledang rivers.

Rivers in Gunung Jerai have $\mathrm{pH}$ ranged from 4.82 to 6.63 which $\mathrm{pH}$ of Teroi River is more acidic $(4.82 \pm 0.21)$ compared to Tupah River and Bt. Hampar rivers (Table 2). $\mathrm{pH}$ reading measured at Gunung Ledang River ranged from 4.36 to 6.36 with Anak Air Puteh River has acidic water (4.36 \pm 0.4$)$ than others. Teroi River and Anak Air Puteh River were located at high altitudes with bedrock embeddedness. It was reported that Neoperla is negatively correlated with BOD $(r=-0.928, p=0.008)$ (Table 3). While, Cryptoperla has a negative correlation with altitudes $(r=-0.883, p=0.02)$. Next, Indonemura showed a positive correlation with altitudes, BOD, and COD $(p<0.05)$, but negatively correlated with water temperature and $\mathrm{pH}(p<0.05)$.

\section{DISCUSSION}

This study documented Plecoptera taxa in rivers that run at different altitude of a mountain. Results showed Plecoptera diversity in rivers located at lower altitudes is more or less similar to those found in rivers at higher altitudes. However, only certain genus can only be found at high altitude levels, for example, Indonemoura sp. from Nemouridae can only be found in Anak Air Puteh River which is located at a higher altitude in Gunung Ledang. The 

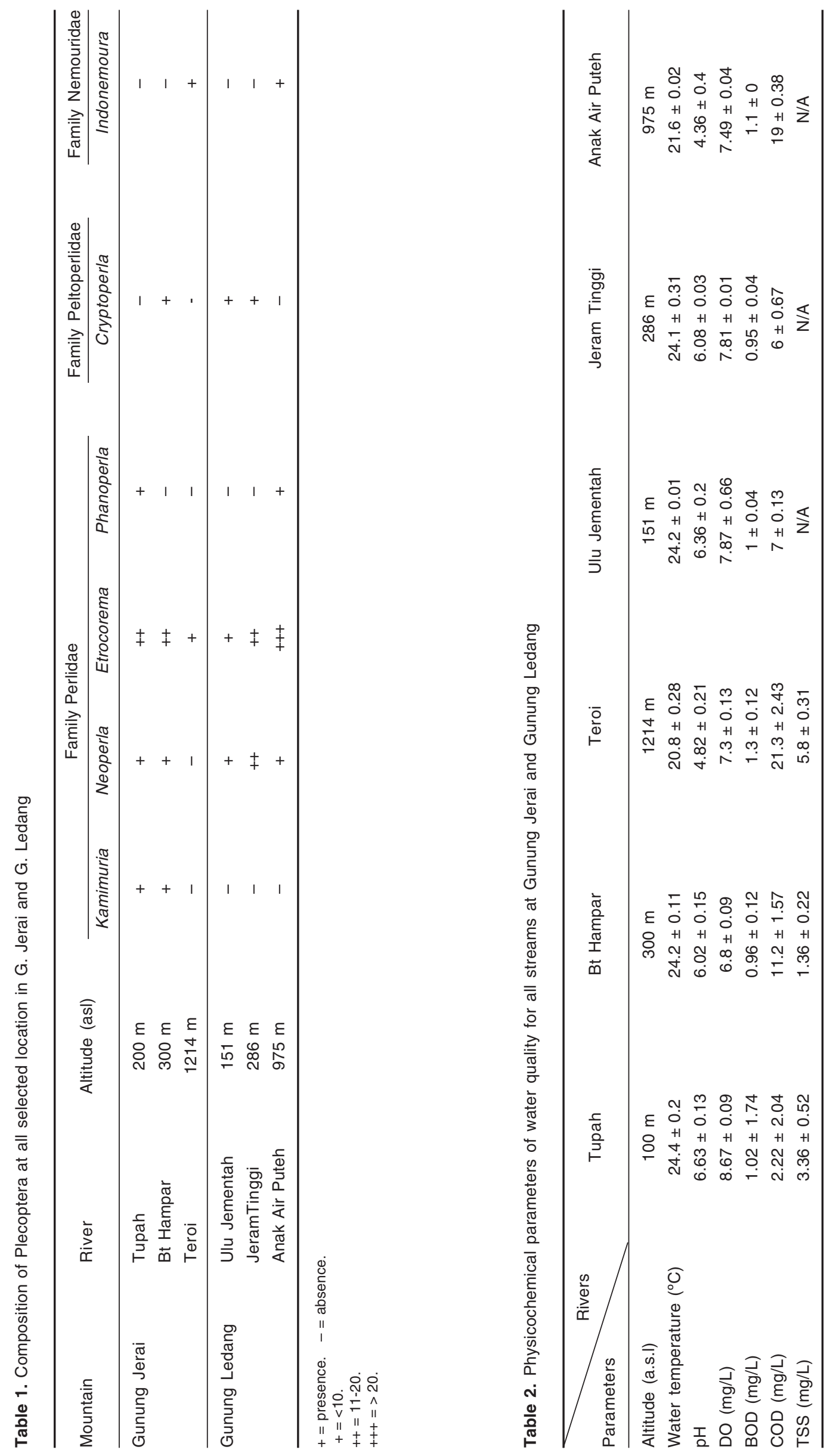
Table 3. Correlation between Plecoptera genus and physicochemical parameter

\begin{tabular}{|c|c|c|c|c|c|c|c|}
\hline Genus & & Altitudes & $\begin{array}{c}\text { Water } \\
\text { Temp }\left({ }^{\circ} \mathrm{C}\right)\end{array}$ & $\mathrm{pH}$ & DO & BOD & COD \\
\hline \multirow[t]{2}{*}{ Kamimura } & Correlation Coefficient & -.270 & .772 & .507 & -.541 & -.135 & -.507 \\
\hline & Sig (2-tailed) & .064 & .072 & .305 & .268 & .798 & .305 \\
\hline \multirow[t]{2}{*}{ Neoperla } & Correlation Coefficient & -.464 & .235 & .203 & .464 & -.928 & -.406 \\
\hline & Sig (2-tailed) & .354 & .654 & .700 & .354 & ${ }^{\star} .008$ & .425 \\
\hline \multirow[t]{2}{*}{ Etrocorema } & Correlation Coefficient & .371 & .000 & -.429 & -.486 & -.314 & .086 \\
\hline & Sig (2-tailed) & .468 & 1.000 & .397 & .329 & .544 & .872 \\
\hline \multirow[t]{2}{*}{ Phanoperla } & Correlation Coefficient & .393 & -.399 & -.655 & .131 & .393 & .393 \\
\hline & Sig (2-tailed) & .441 & .434 & .158 & .805 & .441 & .441 \\
\hline \multirow[t]{2}{*}{ Cryptoperla } & Correlation Coefficient & -.883 & .582 & .736 & .618 & -.765 & -.677 \\
\hline & Sig (2-tailed) & ${ }^{\star} .020$ & .225 & .096 & .191 & 0.76 & .140 \\
\hline \multirow[t]{2}{*}{ Indonemura } & Correlation Coefficient & .828 & -.840 & -.828 & -.207 & .828 & .828 \\
\hline & Sig (2-tailed) & ${ }^{\star} .042$ & ${ }^{\star} .036$ & ${ }^{*} .042$ & .694 & ${ }^{\star} .042$ & ${ }^{\star} .042$ \\
\hline
\end{tabular}

${ }^{*}$ significant $(p<0.05)$.

study managed to record three families of Plecoptera except for the family Leuctridae. Family Perlidae was the most dominant family reported worldwide. Hoang and Bae (2006) also reported Perlidae as one of the stoneflies family that conquer the tropical region. The diversity of the Plecopterans are much greater in North America and Europe (Fochetti \& de Figueroa, 2008) due to several factors such as latitude and temperature. Meanwhile, a family of Leuctridae is rather difficult to be in the collection as they usually residing in the stream bed, burrowing into the sediment (Yule \& Yong, 2004). Due to their small size and having a seasonality life cycle, one might miss the sample during sampling.

Water temperature can affect species distribution and richness along elevational and altitudinal gradients (Madsen et al., 2015). Life cycle characteristics of stream invertebrates such as embryonic development, nymphal growth, emergence, metabolism, and survivorship are determined by stream water temperature (Ketley, 2009; Fengqing et al., 2012) thus, even a slight change in water temperature will affect the freshwater ecosystem including aquatic insect's composition (Macedo et al., 2013). Also, the emergence period of adults, egg hatching as well as longitudinal distribution of Plecoptera are influenced by the water temperature (Ignac \& Catherine, 2012). According to Dewalt et al. (2010), Plecoptera larvae tend to inhabit streams that are well oxygenated and had a low average temperature. Furthermore, differences in stream water temperature can influence the emergence period of Plecoptera species (Cheney et al., 2019). According to Cheney et al. (2019) Amphinemura nigritta (Nemouridae) had a shorter duration of emergence compare to
Leuctra ferruginea (Leuctridae) at an average water temperature of $18.6^{\circ} \mathrm{C}$. In this study, only Indonemura (Nemouridae) had a significant correlation with water temperature $(r=-0.084$, $p=0.036$ ), and was found in Teroi and Anak Air Puteh rivers with mean water temperature ranged from $20.8^{\circ} \mathrm{C}$ to $21.6^{\circ} \mathrm{C}$.

Concomitantly, Plecoptera is considered as a taxonomic group of insects that are acid-tolerant in which only a few species are sensitive towards acidic conditions (Tierney et al., 1998). In this study, Indonemura from family Nemouridae was found at the highest altitudes of Gunung Ledang and Gunung Jerai which are Teroi and Anak Air Puteh rivers, and significantly Indonemura was negatively correlated with $\mathrm{pH}(r=-0.828, p=0.042)$. The statistical analysis showed that $\mathrm{pH}$ had affected the diversity of Indonemura. A number of these genus tends to increase in response to the decreasing $\mathrm{pH}$ value at both study areas. Teroi and Anak Air Puteh rivers had $\mathrm{pH}$ value which is considered acidic since the $\mathrm{pH}$ is less than 5.2 (Tixier \& Guèrold, 2005). The sampling of Plecoptera in the acidic stream by Tixier and Guèrold, (2005), showed that Nemouridae family tends to inhabit an acidic stream. However, Indonemura was absent in their research as this genus can only be found in Malaysia and Borneo (Yule \& Yong, 2004). Nemouridae is listed as food generalists in which, it has no responsibility towards the spatial and temporal variation of food availability (Ledger \& Hildrew 2001; Dangles, 2002). Despite Nemouridae can withstand acidic conditions, several other genera were reported to decrease in response to increasing acidification level especially the species that are acid-sensitive such as from the Perlidae family (Guèrold et al., 
2000). Besides those factors, low water temperature in higher altitude rivers such as Teroi and Anak Air Puteh might also affect the distribution of family Nemouridae. According to Hynes (1976), Nemouridae is numerous in western Europe and was found lesser in the tropics due to a colder climate in Europe which is much preferred by this plecopteran family.

Aquatic insect diversity and composition are affected by geographical gradients and it is very crucial to understand the pattern in biological diversity of this organism because, geographical gradients are an important scope in ecological studies (Jacobsen, 2004). This research provides background information regarding Plecoptera diversity at different altitudes in which the taxa richness of aquatic insects generally decreases as altitudes increases (Brittain \& Milner, 2001). This result was similar to $\mathrm{Xu}$ et al. (2014) in their study at the major river in the world which is Yalutsangpo River. The study done by $\mathrm{Xu}$ et al. (2014) reveals the relationship between the functional feeding Group (FFG) of aquatic insects and the altitudes which involve types of vegetation that exist at different altitudes. The density proportions of collector-gatherers, shredders, and scrapers were related to altitudes and their assemblages vary at different altitudes with different vegetative structures (Tomanova et al., 2007). This study reported most of the Plecoptera genus was found at intermediate altitudes for both Gunung Jerai and Gunung Ledang.

The Plecoptera that were sampled in this research is predators (Kamimura sp., Neoperla sp., Etrocorema sp., and Phanoperla sp.) and shredders (Cryptoperla sp., and Indonemura sp.) (Suhaila \& Che Salmah, 2014). At this intermediate altitude (200 - $300 \mathrm{~m}$ a.s.1.), the riparian area is surrounded by big, and dense canopy trees that adequately supplying fallen leaves for the shredders $(\mathrm{Xu}$ et al., 2014). The decreasing number of shredders with increasing altitudes at both Gunung Jerai and Gunung Ledang proves that their assemblages were affected by the vegetative structure, as the maximum height of the trees became lower with increasing altitudes (Kiew et al., 2010). Riparian trees at the rivers located in higher altitudes $(750-1200 \mathrm{~m})$, usually consist of upper dipterocarp forest and herbaceous flora (Kiew et al., 2010). Those types of flora were lack of canopy cover on the river water surface and thus allochthonous sources (CPOM) are limited for the shredders such as Cryptoperla. Thus, being the reason for only Cryptoperla was found to have $a$ negative correlation $(r=-0.883, p=0.020)$ with altitudes which demonstrates that the Cryptoperla will decrease about increasing altitudes.

\section{CONCLUSION}

Four genera of stoneflies or Plecoptera was recorded in this study and the family Perlidae was found as the diverse genus in all studied rivers. The study on Plecoptera diversity at different altitudes for Gunung Jerai and Gunung Ledang reveals certain parameters that affect the Plecoptera diversity. Indonemura from Nemouridae was reported to be found in rivers at high altitudes (Anak Air Puteh and Teroi rivers) that were located from $750 \mathrm{~m}$ to $1200 \mathrm{~m}$ a.s.1. Although Plecoptera was known to favor the river that is well oxygenated and had low average water temperature, other predictors $(\mathrm{pH}$, altitudes, and BOD) seem to play important roles in shaping the species composition and assemblages in which certain species showed interaction towards low $\mathrm{pH}$ value. With an increasing altitude, the height of the trees and shrubs present also decreasing, thus making the number of shredders decrease with the rising altitudes level. Some species such as Indonemura favors certain parameter such as $\mathrm{pH}$ and altitudes in which influences the assemblages of this Plecoptera genus.

\section{ACKNOWLEDGEMENTS}

This research was funded by Universiti Sains Malaysia, through Research University Individual Grant (1001/PBIOLOGI/8011033). We would like to acknowledge the School of Biological Sciences, Universiti Sains Malaysia for providing the necessary field equipment and facilities needed to carry out this research.

\section{REFERENCES}

Al-Shami, S., Che Salmah, M.R., Nor, S.A.M., Ahmad, A.H. \& Ali, A. 2010. Morphological deformities in Chironomus spp. (Diptera: Chironomidae) larvae as a tool for impact assessment of anthropogenic and environmental stresses on three rivers in the Juru River system, Penang, Malaysia. Environmental Entomology, 39: 210-222.

Al-Shami, S., Che Salmah, M.R., Hassan, A.A. \& Suhaila, A.H. 2011. Influence of agricultural, industrial, and anthropogenic stresses on the distribution and diversity of macroinvertebrates in Juru River Basin, Penang, Malaysia. Ecotoxicology and Environmental Safety, 74(5): 1195-1202. 
Bispo, P.C., Oliveira, L.G., Crisci, V.L. \& Silva, M.M. 2001. Rainfall as a factor in altering the benthic entomofauna (Ephemeroptera, Plecoptera and Trichoptera) in streams in the central highlands of Brazil. Acta Limnologica Brasiliensia, 13(2): 1-9.

Brittain, J.E. \& Milner, A.M. 2001. Ecology of glacier-fed rivers: Current status and concepts. Freshwater Biology, 46(12): 1571-1578.

Cheney, K.N., Roy, A.H., Smith, R.F. \& De Walt, R.E. 2019. Effects of Stream Temperature and Substrate Type on Emergence Patterns of Plecoptera and Trichoptera From Northeastern United States Headwater Streams. Environmental Entomology, 48(6): 1349-1359.

Dangles, O. 2002. Functional plasticity of benthic macroinvertebrates: implications for trophic dynamics in acid streams. Canadian Journal of Fisheries and Aquatic Sciences, 59: 1-11.

Dewalt, E.R., Vincent, H.R. \& William, L.H. 2010. Ecology and classification of North American Freshwater Invertebrates (Third Edition). pp 587-657.

Fengqing, L., Qinghua, C., Wanxiang, J. \& Xiaodong, Q. 2012. Macroinvertebrate relationships with water temperature and water flow in subtropical monsoon streams of Central China: implications for climate change. Fundamental and Applied Limnology, 180 (3): 221-231.

Fochetti, R. \& Tierno de Figueroa, J.M. 2008. Global diversity of stoneflies (Plecoptera; Insecta) in freshwater. Hydrobiologia, 595: 365-377.

Guèrold, F., Boudot, J.P., Jacquemin, G., Vein, D., Merlet, D. \& Rouiller, J. 2000. Macroinvertebrate community loss as a result of headwater stream acidication in the Vosges Mountains (N-E France). Biodiversity and Conservation, 9: 767-783.

Hoang, D.H. \& Bae, Y.J. 2006. Description of three new species of Neoperla (Plecoptera: Perlidae) and a historical review of tropical Southeast Asian Perlidae. Journal Zoo Taxa, 1453 (1): 4154.

Hoang, T.H., Lock, K., Chi Dang, K., De Pauw, N. \& Goethals, P.L.M. 2010. Spatial and temporal pattern of macroinvertebrates communities in the Du River Basin in Northern Vietnam, Journal of Freshwater Ecology, 25: 637-647.

Ignac, S. \& Catherine, M.Y. 2012. Insecta: Plecoptera. Freshwater invertebrates of Malaysian Region. Academy of Sciences Malaysia. pp 448-451.

Jacobsen, D. 2004. Contrasting patterns in local and zonal family richness of stream invertebrates along an Andean altitudinal gradient. Freshwater Biology, 49(10): 1293-1305.
Jaihao, R. \& Phalaraksh, C. 2013. Relationship between water quality and distribution of stonefly larvae in pristine areas at Huai Nam Dung National Park, Thailand, KKU Science Journal, 41(3): 709-722.

Ketley, Z. 2009. Stream invertebrate and water temperature: evaluating thermal tolerances in the Cape floristic region (South Africa) implications of climate change. Master thesis. University of Cape Town.

Kiew, R., Chung, R., Saw, L., Soepadmo, E. \& Boyce, P. 2010. Flora of Peninsular Malaysia Series II: Seed Plants. Forest Research Institute Malaysia. pp 21-30.

Ledger, M.E. \& Hildrew, A.G. 2001. Growth of an acid tolerant stoney on epilithic biolms from streams of contrasting pH. Freshwater Biology, 46: 1457-1470.

Lock, K. \& Goethals, P.L.M. 2008. Distribution and ecology of the stoneies (Plecoptera) of Flanders (Belgium). Annal Limnology - International Journal of Limnology, 44: 203-213.

Macedo, M.N., Coe, M.T., DeFries, R., Uriarte, M., Brando, P.M., Neill, C. \& Walker, W.S. 2013. Land-use driven stream warming in southeastern Amazonia. Philosophical Transactions of the Royal Society B. 1-9.

Madsen, P.B., Morabowen, A., Andino, P., Espinosa, R., Cauvy-Fraunie, S., Dangles, O. \& Jacobsen, D. (2015). Altitudinal distribution limits of aquatic macroinvertebrates: an experimental test in a tropical alpine stream. Ecological Entomology, 40(5): 629-638.

Merritt, R.W., Cummins, K.W. \& Berg, M.B. (2008). Introduction to Aquatic Insects in North America 4th Edition. Kendall Hunt Publishing.

Ratitorn, J. \& Chitchol, P. 2013. An illustrated key to stonefly larvae (Plecoptera, Insecta) at Huai Nam Dung National Park, Thailand. Journal of Current Science and Technology, 3(1): 25-38.

Suhaila, A.H. \& Che-Salmah, M.R. 2010. Application of Aquatic Insects (Ephemeroptera, Plecoptera and Trichoptera) in water quality assessment of Malaysian Headwater. Tropical Life Sciences Research, 28(2): 143-162.

Suhaila, A.H. \& Che-Salmah, M.R. 2011. Influence of substrate-embeddedness and canopy cover on the abundance and diversity of Ephemeroptera, Plecoptera and Trichoptera (EPT) in recreational rivers. Aquatic Insects, 33: 281-292.

Suhaila, A.H. \& Che-Salmah, M.R. 2014. Ecology of Ephemeroptera, Plecoptera and Trichoptera (Insecta) in Rivers of the Gunung Jerai Forest Reserve: Diversity and Distribution of Functional Feeding Groups. Tropical Life Sciences Research, 25(1): 61-73. 
Tierney, D., Kelly-Quinn, M. \& Bracken, J.J. 1998. The faunal communities of upland streams in the eastern region of Ireland with reference to aorestation impacts. Hydrobiologia, 389: 115130.

Tixier, G. \& Guèrold, F. 2005. Plecoptera response to acidication in several headwater streams in the Vosges Mountains (northeastern France). Biodiversity and Conservation, 14: 1525-1539.

Tomanova, S., Tedesco, P.A., Campero, M., Van Damme, P.A., Moya, N. \& Oberdorff, T. 2007. Longitudinal and altitudinal changes of macroinvertebrate functional feeding groups in neotropical streams: a test of the river continuum concept. Fundamental and Applied Limnology, 170(3): 233-241.
William, D.D. \& Felmate, B.W. 1992. Aquatic Insects. Aquatic Conservation Marine and Freshwater Ecosystem, 3(3): 284-285.

$\mathrm{Xu}$, M., Wang, Z., Pan, B. \& Yu, G. 2014. The assemblage characteristics of benthic macroinvertebrates in the Yalutsangpo River, the highest major river in the world. Earth Science, 8(3): 351-361.

Yule, C.M. \& Yong, H.S. 2004. Freshwater Invertebrates of Malaysia Region. Academy of Sciences Malaysia. 448-451.

Zwick, P. 2000. Phylogenetic System and Zoogeography of the Plecoptera. Annual Review of Entomology, 45: 709-746. 
